\section{Foliicolous fungi of Kodaikanal, Tamil Nadu, India}

\author{
V.B. Hosagoudar ${ }^{1}$, V. Dhivaharan ${ }^{2}, \mathrm{~K}$. Thiyagesan $^{2}$ \& \\ K. Kandavel ${ }^{2}$
}

1 Tropical Botanic Garden and Research Institute, Palode, Thiruvananthapuram, Kerala 695562, India

${ }^{2}$ Centre for Mycological Research, Sengamala Thayaar Educational Trust Women's College, Mannargudi, Tamil Nadu 614001, India Email: vbhosagoudar@rediffmail.com

The survey of foliicolous fungi during Feb-March 2007 in the montane forests of Kodaikanal in Madurai District of Tamil Nadu resulted in the discovery and reporting of three interesting taxa besides a new species of Phyllachora. Mahonia leschenaultii (Berberidaceae) and Phoebe sp. (Lauraceae) were found infected with rust fungi; both these rust fungi formed telial columns bearing black hair-like growths on the abaxial surface of the leaves. While the former host did not show much difference with rest of the leaf portion, the latter host developed tender blisters on which telia are borne. Probably, to hold the weight of the columns, they were deeply seated in the host.

\section{Enumeration \\ 1. Gambleola cornuta Massee (Pucciniosiraceae) (Image 1)}

Gambleola cornuta Massee, Bull. Misc. Inform. Kew 1898: 115, 1898. Pucciniosira cornuta (Massee) Burified \& J.F. Henner (1988).

Pycnia, aecia and uredinia not seen. Telia in columns of 10-20 in number, hypophyllous, born on dark spots, originate subepidermally, deeply sunk in the host tissue, cupulate. Telial initials originate beneath the epidermis by forming coarse hyphal strands. Large numbers of rectangular, pale, thin walled cells produce columnar telial structures bordered with globose cells. While central cells produce telial columns, bordered cells produce peridial layer. Telial columns up to $10 \mathrm{~mm}$ long

Date of publication (online): 26 February 2010

Date of publication (print): 26 February 2010

ISSN $0974-7907$ (online) | 0974-7893 (print)

Editor: Vatsavaya S Raju

Manuscript details:

Ms \# 02056

Received 13 September 2008

Final received 15 January 2010

Finally accepted 11 February 2010

Citation: Hosagoudar, V.B., V. Dhivaharan, K. Thiyagesan \& K. Kandavel (2010). Foliicolous fungi of Kodaikanal, Tamil Nadu, India. Journal of Threatened Taxa 2(2): 705-708

Copyright: (C) V.B. Hosagoudar, V. Dhivaharan, K. Thiyagesan \& K. Kandavel 2010. Creative Commons Attribution 3.0 Unported License. JoTT allows unrestricted use of this article in any medium for non-profit purposes, reproduction and distribution by providing adequate credit to the authors and the source of publication.

Acknowledgements: We are thankful to Dr. S. Ganeshan, Director, Tropical Botanic Garden and Research Institute, Palode, Thiruvananthapuram, Kerala for the facilities. We are grateful to Forest Department, Govt. of Tamil Nadu for the forest permission.

\section{OPEN ACGESS | FREE DOWNLOAD}

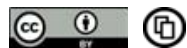

and up to $0.5 \mathrm{~mm}$ broad, straight, curved, coiled like tendrils, dry, horney, brownishblack; teliospores formed successively from the basal hymenium, developed in chains, laterally coalescent to form firm spore column; spores two-celled with horizontal septum, brown, attenuated towards both terminals, catenate with intercalary cells firmly united laterally and longitudinally, cells $38-48 \times 14-19 \mu \mathrm{m}$, wall smooth, $2-4 \mu \mathrm{m}$ thick; intercalary cells pale, cylindrical, up to $15 \mu \mathrm{m}$ long; telial column capsuled in peridial cell layer, peridial cells fusiform, elongated, 25-36x15-20 $\mu \mathrm{m}$, smooth-walled.

Material examined: 08.iii.2007, on living leaves of Mahonia leschenaultii (Berberidaceae), Then shola, Kodaikanal, Madurai, Tamil Nadu, V.B. Hosagoudar et al. HCIO 48064, TBGT 2847.

This is an endemic unispecific rust known from India. (i) It was described on leaves of Berberis nepalensis (= Mahonia napaulensis) from Chakrata (Gamble), Mussorie and Kumaon (Butler), and there are two collections of it at IMI gathered on 23 May 1957 by E. Müller \& B.D. Sanwal from Uttar Pradesh. (ii) It was collected earlier from Nilgiris (Fischer) and recently (1962-63) from Kodaikanal (Raghunathan \& Ramakrishnan 1972). Therefore, the present collection is after a lapse of more than four decades. It is to be noted that the host Mahonia napaulensis is distributed in northern India whereas $M$. leschenaultii (Wight \& Arn.) Takeda ex Dunn occurs in southern India. It is interesting to record that the latter host taxon was treated as a variety under the former - first as Berberis
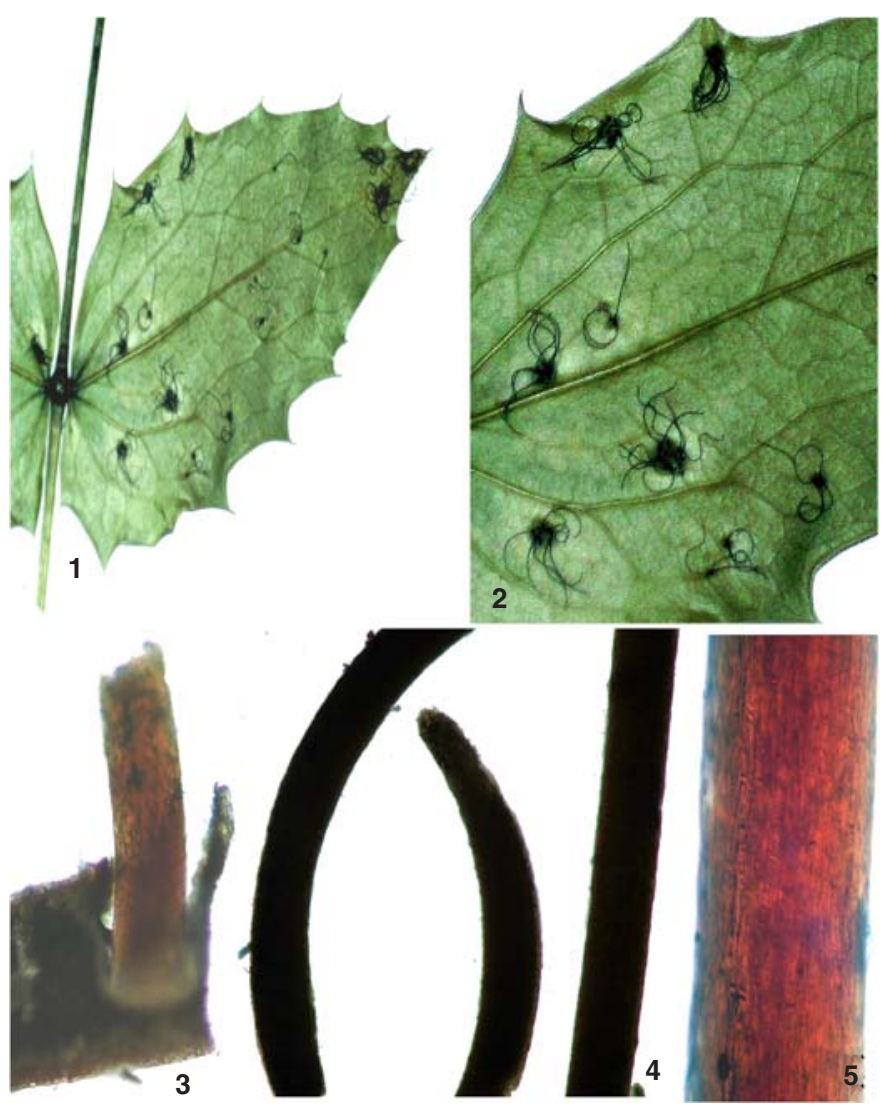

Image 1. Gambleola cornuta Massee

1 - Infected leaf; 2 - Telial columns on dark spots; 3 - Cupulate base of the telial column; 4 - Telial columns with apical tip; 5 - Cellular telial column 
napaulensis var. leschenaultii (Wight \& Arn.) Hook.f. \& Thomson and later as Mahonia napaulensis var. leschenaultii (Wight \& Arn.) Fedde.

\section{Kernella lauricola (Thirum.) Thirum. (Pucciniaceae) (Image 2)} 1949.

Kernella lauricola (Thirum.) Thirum., Mycologia 41: 97,

Kernia lauricola Thirum., Mycologia 38(6): 685, 1947.

Puccinia lauricola (Thirum.) Raghunathan \& K. Ramakr., Mysore J. Agric. Sci. 7(1): 72, 1973, non Cummins, 1949.

Pycnia, aecia and uredinia not seen. Telia present. This rust causes hypertrophy, form blisters of $3-8 \mathrm{~cm}$ in diameter on the abaxial surface the corresponding upper portion of the leaf surface depressed and pushed inside. Telia in columns, 10-20 telial columns produced on the blistered portion, 10-20 $\mathrm{mm}$ long, dark-brown, simple, straight, curved, twisted like tendrils, originate sub-epidermally, deep seated in to the host tissues, cupulate, non-peridiate, produce two-celled, long pedicellate teliospores in loosely packed columns. Teliospores pale brown to brown, oblong, uniseptate, septum horizontal, 24-46x18-26 $\mu \mathrm{m}$, both cells equal in size, wall deep brown, smooth, 3-8 $\mu \mathrm{m}$ thick. Pedicels pale yellow, persistent, 40$100 \times 4-8 \mu \mathrm{m}$

Materials examined: 08.iii.2007, on leaves of Phoebe sp. (Lauraceae), Then shola, Kodaikanal, Tamil Nadu, V.B. Hosagoudar et al. HClO 48071, TBGT 2854.

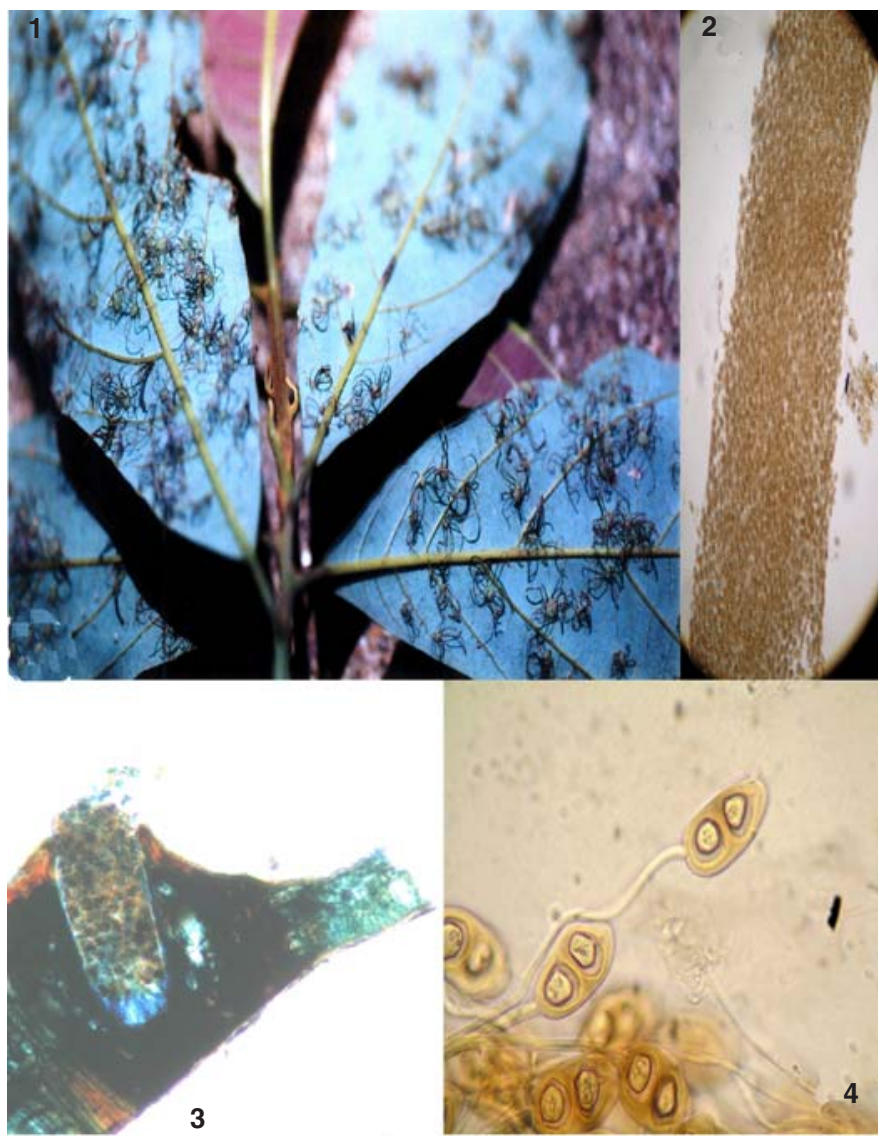

Image 2. Kernella lauricola (Thirum.) Thirum.

1 - Telial columns on the blisters; 2 - part of the telial column; 3 Cupulate telial base on the hypetrophied portion and the normal leaf thickness at the right side; 4 - Pedicellate two celled teliospores
The genus Kernella Thirum. (1949) was published as a new name for Kernia Thirum. (1947), which is a later homonym (non Nieuwland 1916). Although Thirumalachar (I.c. 1949) clearly stated that his Kernella lauricola is a nomen novum, this name was based on his earlier illegitimate genus Kernia. Therefore, there is a requirement to make use of the specific epithet and create the combination, Kernella lauricola (Thirum.) Thirum. Perhaps, it could be the reason for the discrepancy in the author citation of this taxon in literature. Kernella is a unispecific genus and was merged with Puccinia by some authors, and the combination proposed by Raghunathan \& Ramakrishnan (1973) is illegitimate in view of pre-occupied Puccinia lauricola by Cumminis (1949). No new name is proposed here since earlier Cummins \& Hiratsuka (1983) and currently the present authors consider Kernella as distinct from Puccinia because of the formation of the telial columns. This taxon was collected from Nilgiris between years 1945-62; the present collection is after a lapse of more than four decades and located in Kodaikanal hills for the first time.

\section{Phyllachora sageretiae sp. nov. (Phyllochoraceae)}

During the survey in the shola forests of Kodaikanal hills, leaves of Sageretia hamosa were found infected with the tar spot disease causing fungus. Microscopic study of the fungus revealed that it is different from its allied species, Phyllachora rhamni, known on Rhamnus wightii from Udhagamandalam. Hence, it is described and illustrated in detail.

\section{Phyllachora sageretiae sp. nov.} (Image 3)

Maculae infectionis nullae. Stromata epiphylla, dispersa, elevata, nigra, nitida, rotunda vel ovata, 1-2mm diam., 1-3loculata. Perithecia globosa vel craterviformes, subepidermalis posita, ostiolata, 280-330x90-120 $\mu \mathrm{m}$, clypeata; clypeus nigrum, solum superiorum positus, 60$100 \mu \mathrm{m}$ crassus; asci numerosi, cylindrici, octospori, paraphysati, directus ad ostiolatus, leniter stipitati, 60-100x8$10 \mu \mathrm{m}$, apparatus apicalis distinctus; paraphyses hyalinae, filiformes, directus ad ostiolatus; ascosporae plerumque uniseriatae, raro irregularis, hyalinae, oblongae, ellipsoideae, fusiformes vel obclavatae, utrinque late rotundatae vel leniter attenuatae ad basim, leniter obliquetus positae, saepe leniter constrictae ad medius vel profunde inquinatae, 14-16x4-6 $\mu \mathrm{m}$.

Infection spots absent. Stromata epiphyllous, scattered, raised, black, shining, round to oval, $1-2 \mathrm{~mm}$ in diameter, loculate, locules 1-3 per stromata. Perithecia globose to bowlshaped, subepidermal, ostiolate, 280-330x90-120 $\mu \mathrm{m}$, clypeate, clypeus black, only at the adaxial surface, 60-100 $\mu \mathrm{m}$ thick; asci numerous, cylindrical, octosporous, paraphysate, directed towards ostiole, slightly stipitate, 60-100x8-10 $\mu \mathrm{m}$, apical apparatus well defined; paraphyses hyaline, filiform, directed towards the ostiole; ascospores predominantly uniseriate, rarely irregular, hyaline, oblong, ellipsoidal, fusiform to obclavate, broadly rounded to slightly attenuated at the base, slightly obliquely placed, slightly constricted and deeply stained with cotton blue at the middle, 14-16x4-6 $\mu \mathrm{m}$.

Material examined: 06. ii.2007, on living leaves of Sageretia hamosa Brongn. (Rhamnaceae), Kookal shola, Kodaikanal, Tamil Nadu, India, V.B. Hosagoudar et al. HClO 48074 (Holotype), TBGT 2857 (isotype).

Phyllachora rhamni T.S. Ramakr. is known on Rhamnus wightii from Udahagamandalam, a high altitude montane forest 

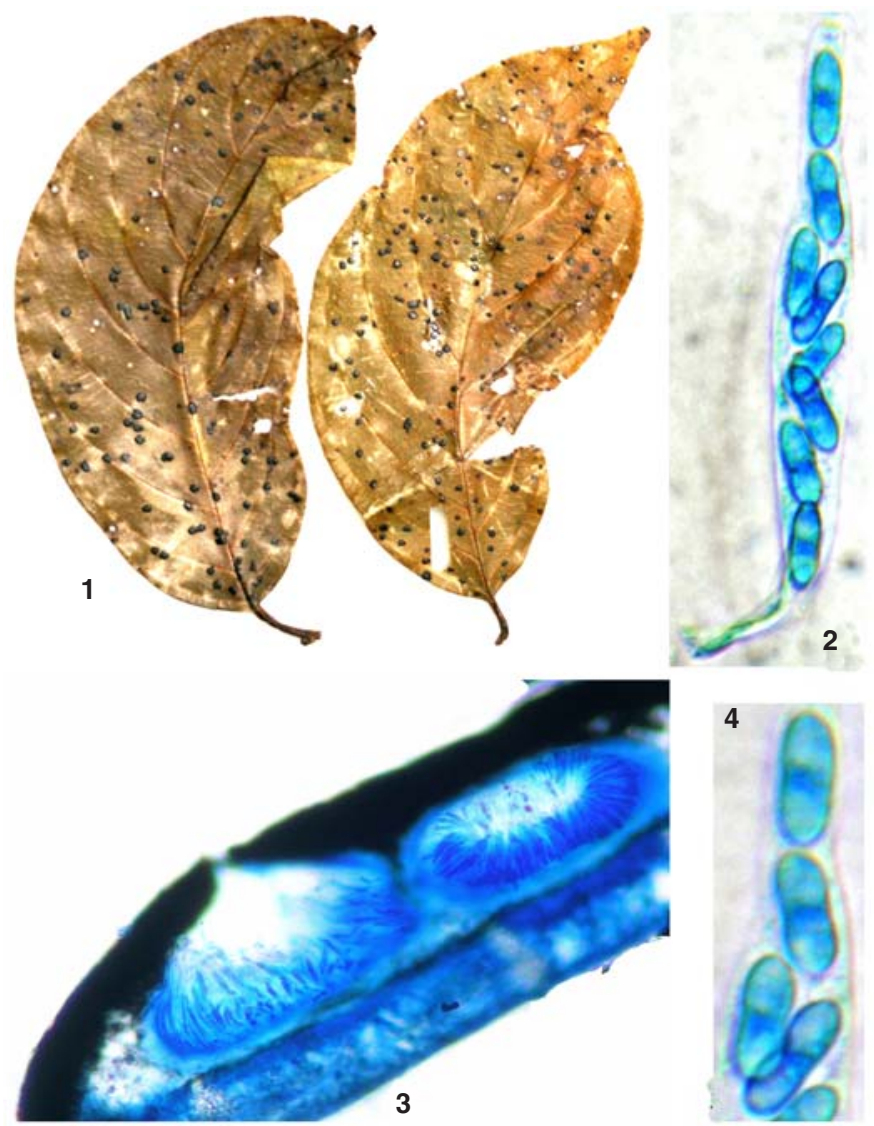

Image 3. Phyllachora sageratiae sp. nov.

1 - Infected leaves; 2 - Ascus; 3 - T.S. through stromata showing perithecia; 4 - Ascospores

element in Tamil Nadu (Ramakrishnan 1950; Kamat et al. 1978). However, Phyllachora sageretiae differs from it in not producing infection spots around stromata besides the stromata are restricted to the leaf adaxial surface. Further, ascospores are oblong, ellipsoidal to obclavate with slight constriction and stain very deeply in the middle portion.

\section{Trochophora fasiculata (Berk. \& M.A. Curtis) Goos (Mycospherellaceae) (Image 4)}

Trochophora fasiculata (Berk. \& M.A. Curtis) Goos [as 'fasiculatum'], Mycologia 78: 759, 1986.

Helicoma fasiculatum Berk. \& M.A. Curitis in US North Pacific Exped., No. 142, 1853-1856.

Trochophora simplex (Petch) R.T. Moore, Mycologia 47: 90, 1955.

Helicostilbe simplex Petch, Roy. Bot. Gard. Peradeniya, Ann. 7: 321, 1922.

Colonies hypophyllous, dark, brownish dark to dark, waxy, raised, $2-4 \mathrm{~mm}$ in diameter, surrounded by yellow haloes. Synnemata subepidermal, dark hyphae borne from the base of the synnemata and ramify into the host tissue, synnemata brownish black, erect, 150-600x8-38 $\mu \mathrm{m}$ at the middle, 22$83 \mu \mathrm{m}$ broad at the base. Conidiophores macronematous, synnematous, mostly simple, rarely branched, straight, flexuous, narrow, cylindrical, closely adpressed along most of their length, swollen and spreading at the apex, pale brown, $2-4 \mu \mathrm{m}$ broad at the lower side, $4-8 \mu \mathrm{m}$ broad at the apical portion; conidiogenous cells polyblastic, integrated, terminal, determinate to sympodial, clavate. Conidia solitary, dry,
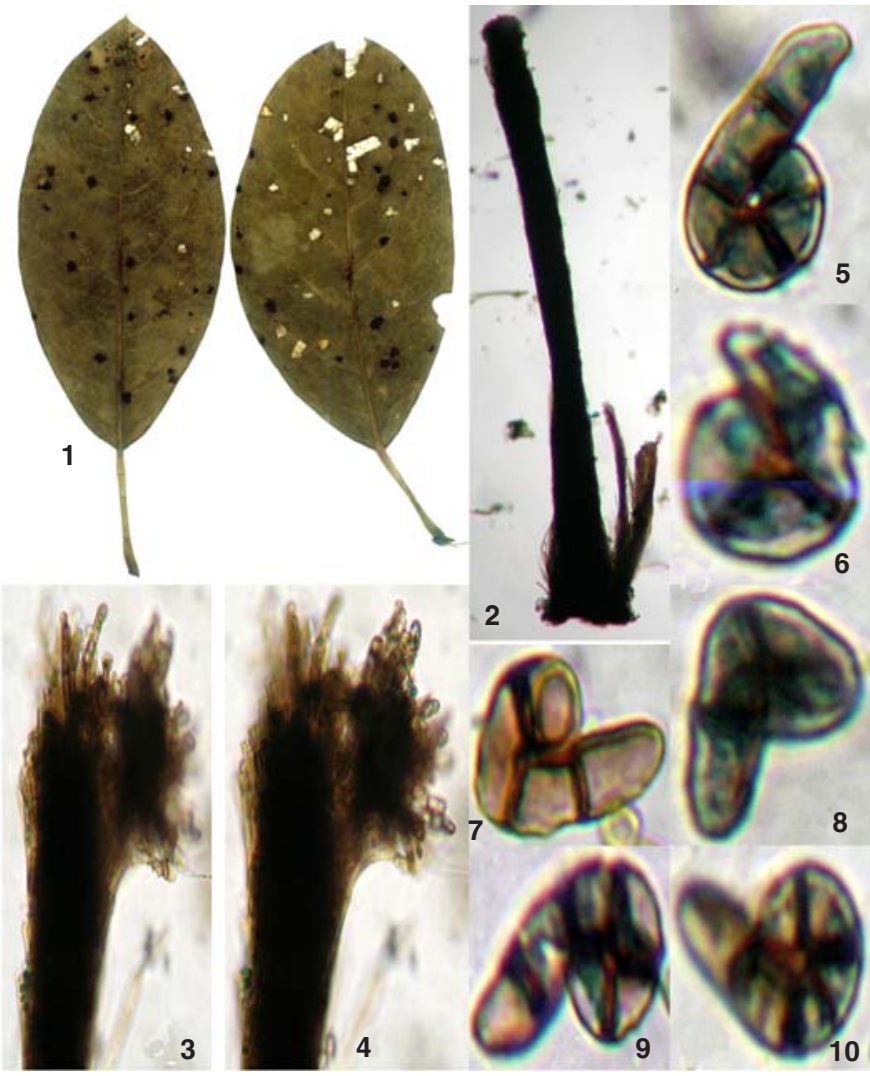

Image 4. Trochophora simplex (Petch) Moore

1 - Infected leaves; 2 - Synnema; 3-4 - Apical portion of synnemata; 5-10 - Conidiospores

produced at many points on the curved conidiogenous cells, simple, strongly curved to helicoids, pale brown, smooth, transversely 2-3-septate, septa deeply black, 13-29x8-10 $\mu \mathrm{m}$.

Material examined: 09.iii.2007, on living leaves of Daphniphyllum neilgherrense (Wight) Rosenth. (Daphniphyllaceae), Mathikettan shola, Kodaikanal, Tamil Nadu, V.B. Hosagoudar HCIO 48063, TBGT 2846.

Daphniphyllum neilgherrense is known to be infected by two foliar fungal parasites, namely, Asterostomella daphniphylli Hosag. \& K. Ravik. and Trochophora fasiculata (Berk. \& M.A. Curtis) Goos. The former fungus is known only from Kodaikanal (type locality); it infects adaxial surface of the leaves but produces no pathogenic symptoms. The latter species infects the abaxial surface of leaves, causes yellowing around the infected spots. Almost all helicosporous hyphomycetes are saprobic but for a few members like Dichotomorphthoropsis, Helicomina, Helicohoidion and Trochophora which are known to be pathogens (Zhao et al. 2007).

Goos (1986) examined the specimens of Helicoma simplex (Sydow) Linder, H. fasciculatum Berk. \& M.A.Curtis and Trochophora simplex (Petch) R.T. Moore and concluded that they are conspecific. Trochophora fasiculata was reported on Daphniphyllum sp. from Sri Lanka, Hongkong and Taiwan (Ellis 1971). In India, it was reported from Kotagiri (Nilgiris) and Kodaikanal in 1955 (Bilgrami et al. 1991). Conversely, the fungus is re-located in Kodaikanal after a lapse of more than five decades.

\section{References}

Bilgrami, K.S., S. Jamaluddin, \& M.A. Rizwi (1991). Fungi of India. List and References. Today and Tomorrow's Printers \& Publish- 
ers, New Delhi, 798pp.

Cummins, G.B. \& Y. Hiratsuka (1983). Illustrated Genera of Rust Fungi. The American Phytopathological Society, Minnesota.

Ellis, M.B. (1971). Dematiaceous Hyphomycetes. CMI, Kew, Surrey, England.

Goos, R.D. (1986). A review of the anamorph genus Helicoma. Mycologia 78: 744-761.

Kamat, M.N., V.S. Seshadri \& A.A. Pande (1978). A Monographic Study of Indian Species of Phyllachora. UAS Hebbal, Mon. Ser. 4, Bangalore, 100pp.

Nieuwland, J.A. (1916). Critical notes on new and old genera of plants. Amer. Midi. Nat. 4: 379.

Raghunathan, A.N. \& K. Ramakrishnan (1972). Rust fungi of Madras State-I. Mysore Journal of Agricultural Science 6: 285299.

Raghunathan, A.N. \& Ramakrishnan, K. (1973). Rust fungi of Madras State. Ibid. 7: 62-72.

Ramakrishnan, T.S. (1950). Additions to the fungi of Madras-X. Proceedings of Indian Academy of Science 34: 63-72.

Zhao, G.H., X.Z. Liu \& W.P. Wu (2007). Heliosporous hypomycetes from China. Fungal Diversity 26: 313-524. 